\title{
Measurement of Natural Radioactivity and Radon Exhalation Rate in Coal Ash Samples from a Thermal Power Plant
}

\author{
Aziz Boukhair 1,2*, Laila Belahbib', Khadija Azkour³, Hamid Nebdi', \\ Mohammed Benjelloun1, Abdelmjid Nourreddine ${ }^{4}$ \\ ${ }^{1}$ Laboratoire de Physique Nucléaire, Atomique et Moléculaire, Département de Physique, Faculté des Sciences \\ Université Chouaib Doukkali, El Jadida, Morocco \\ ${ }^{2}$ Centre Régional des Métiers de l'Education et de la Formation, El Jadida, Morocco \\ ${ }^{3}$ Ministère de l'Intérieur, Secrétariat général, Province d'El Jadida, Morocco \\ ${ }^{4}$ Groupe RaMsEs, Institut Pluridisciplinaire Hubert Curien (IPHC), Université de Strasbourg, Strasbourg, France \\ Email: *mouad.boukhair@gmail.com
}

Received 3 June 2016; accepted 8 July 2016; published 11 July 2016

Copyright (C) 2016 by authors and Scientific Research Publishing Inc.

This work is licensed under the Creative Commons Attribution International License (CC BY). http://creativecommons.org/licenses/by/4.0/

(c) (i) Open Access

\begin{abstract}
Coal is the main energy source for electricity generation in the world. In Morocco, $37 \%$ of electricity generation comes from combustion coal in thermal power plants. This combustion process generates large amounts of fly and bottom ashes. In recent years, these ashes became a great topic of interest because of their different uses and especially in construction materials. In this work, we assess radiation risks due to natural radioactivity in samples of fly and bottom ashes collected from JLEC (Jorf Lasfar Energy Company) thermal power plant, and different analyses are performed through two nuclear techniques such as gamma spectrometry and alpha dosimetry based on the use of LR115 films detectors. Our analysis shows that ${ }^{226}$ Ra activities and ${ }^{232} \mathrm{Th}$ in both ash samples are well above the permissible activity. The values of the external risk index $\left(\mathrm{H}_{\mathrm{ex}}\right)$ and internal one $\left(\mathrm{H}_{\text {in }}\right)$ for these ashes are below unity, with the exception of 1.28 in fly ash for $\mathrm{H}_{\text {in. }}$ The obtained values for the equivalent radium $R_{e}$ eq and annual effective doses $\dot{E}$ in fly and bottom ashes are $324 \mathrm{~Bq} / \mathrm{kg}$ and $210 \mathrm{~Bq} / \mathrm{kg}$, and $0.18 \mathrm{mSv} / \mathrm{y}$ and $0.11 \mathrm{mSv} / \mathrm{y}$, respectively. The surface radon exhalation rates for the samples of fly and bottom ashes are $276 \mathrm{mBq} \cdot \mathrm{m}^{-2} \cdot \mathrm{h}^{-1}$ and 381 $\mathbf{m B q} \cdot \mathrm{m}^{-2} \cdot \mathrm{h}^{-1}$, respectively. Based on these results, we have shown that fly ash and bottom one from thermal power plant JLEC didn't have, in any case, a health risk to the public so it can be effectively used in various construction activities.
\end{abstract}

\footnotetext{
${ }^{*}$ Corresponding author.
} 


\section{Keywords}

\section{Natural Radioactivity, Gamma Spectrometry, LR115, Fly Ash, Bottom Ash, Equivalent Radium, Annual Effective Doses, Exhalation of Radon}

\section{Introduction}

The socio-economic development of Morocco and the major projects being initiated in all sectors, particularly the global rural electrification program, contributed strongly to increase the national request of energy. The main source of energy for the electricity production comes from the coal combustion in thermal power plants [1]. This combustion generates large amounts of solid residues such as fly and bottom ashes. The radioactivity content of different mineral coal is very heterogeneous and varies depending on their origin. Generally, coal contains radionuclides with activity ranging from 30 to $100 \mathrm{~Bq} / \mathrm{kg}, 10$ to $600 \mathrm{~Bq} / \mathrm{kg}$ and 10 to $200 \mathrm{~kg} / \mathrm{Bq}$, for ${ }^{40} \mathrm{~K}$, ${ }^{238} \mathrm{U}$ and ${ }^{232} \mathrm{Th}$, respectively [2]. The specific activity of the coal ash can reach three to five times higher than the original one. This is called Technologically Enhanced Naturally Occurring Radioactive Materials (TENORM). While the levels of radioactivity of these ashes remain moderate, a prolonged exposure may become significant when large quantities of these ashes are landfilled or recycled in building materials. The use of coal ashes has economic advantages but can affect the doses received by the human being indoors. Indeed, this use increases the external and internal radiations due to inhalation or ingestion of radon and its descendants [3].

Radon-222 is the most commonly measured because of its relatively long period (3.824 d). It is an odorless natural radioactive gas, and is the main source of radiation exposure for humans. Its contribution is estimated at more than half of the average annual dose after natural radioactivity received by the population [4]. In 1987, the International Agency for Research on Cancer (IARC) of the World Health Organization (WHO) recognized radon as lung human carcinogen [5].

In the present work, we assess the radiation hazards due to natural radioactivity in coal ash from radionuclides of three chains of radioactive decay $\left({ }^{238} \mathrm{U},{ }^{235} \mathrm{U}\right.$ and $\left.{ }^{232} \mathrm{Th}\right)$ and ${ }^{40} \mathrm{~K}$, calculations of external hazard index $\left(\mathrm{H}_{\mathrm{ex}}\right)$ and internal one $\left(\mathrm{H}_{\mathrm{in}}\right)$, the equivalent radium $\left(\mathrm{Ra}_{\mathrm{eq}}\right)$, the absorbed dose rate $(\dot{\mathrm{D}})$, the annual effective dose $(\dot{\mathrm{E}})$ and the radon exhalation rate $\left(E_{\mathrm{x}}\right)$ are performed on samples of fly and bottom ashes delivered by the thermal power plant of Jorf Lasfar Energy Company (JLEC), the first private electricity producer in Morocco.

\section{Overview of the Thermal Power Plant of JLEC}

The power plant of JLEC is the largest thermal coal one, independent of Middle East and North Africa. It is the main provider of the National Office of Electricity and Water Supply in Morocco with a total annual production capacity about $2056 \mathrm{MW}$ of electricity [6]. It is located in the port Jorf Lasfar, which is $127 \mathrm{~km}$ far from the southwest of Casablanca, on the Atlantic Ocean coast. It occupies an area of 60 hectares and is located on a narrow strip of land between a $60 \mathrm{~m}$ cliff height on the East and West Atlantic Ocean as shown in Figure 1.

In JLEC thermal power plant, coal combustion generates large masses of solid wastes that exceed 640,000 tons per year. Fly ashes are a majority and are around 500,000 tons per year. And for the bottom ones, the production rate exceeds 50,000 tons per year [7].

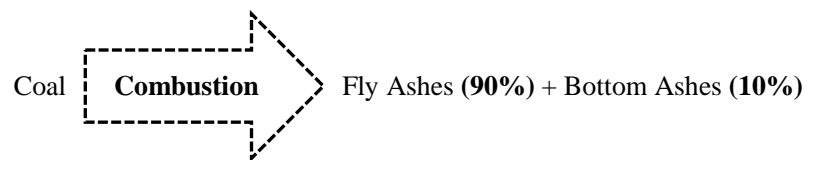

Today, $80 \%$ - $95 \%$ of fly ash is valued by some national cement, while the bottom ash continues to be stored in large quarries.

\section{Materials and Methods}

In the present work, we evaluate radiation hazards due to natural radioactivity in coal ash from radionuclides of three chains of radioactive decay $\left({ }^{238} \mathrm{U},{ }^{235} \mathrm{U}\right.$ and $\left.{ }^{232} \mathrm{Th}\right)$ and ${ }^{40} \mathrm{~K}$. Our analyzes were carried out on samples of fly 


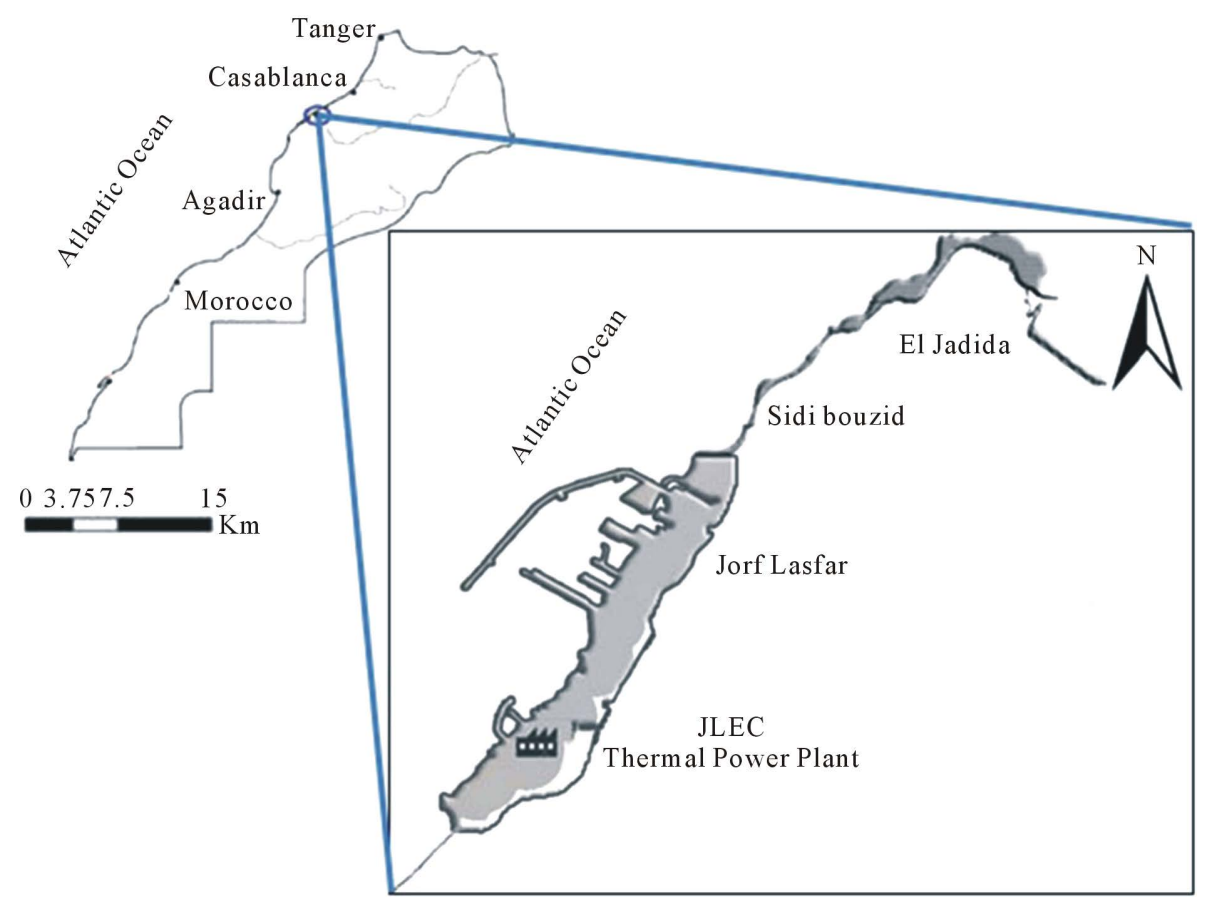

Figure 1. The power plant Jorf Lasfar Energy Company (JLEC).

and bottom ashes delivered by the thermal power plant JLEC using two nuclear techniques: gamma spectrometry for identifying the gamma radio transmitters and quantify their activities, and alpha dosimetry based on quantitative exploitation of Solid-State Nuclear Track Detectors (SSNTD, LR115).

Before any measures and for homogeneous samples, fly and bottom ashes were dried in stove at $40^{\circ} \mathrm{C}$ during 24 hours, then crushed and sieved through a sieve of $100 \mu \mathrm{m}$. The sieved samples were packaged in sealed radon containers for at least 4 weeks to establish secular equilibrium corresponding to seven half-lives of ${ }^{222} \mathrm{Rn}$.

\subsection{Samples Activities of Coal Ash}

To measure the natural radioactivity in coal ash, samples of fly and bottom ashes were studied and analyzed by gamma ray spectrometer with Broad Energy Germanium detector (BEGe) at the Multidisciplinary Institute Hubert Curien in Strasbourg, France. This is a Hyper-Pure Germanium planar type HPGe detector associated with a set of electronic modules for the pulse shaping, amplification and storing of pulses delivered during the passage of gamma radiation through the detector. Its area of energy measurement is 30 to $3000 \mathrm{keV}$ with a resolution of $0.633 \mathrm{keV}$ to $122 \mathrm{keV}$, and $1.934 \mathrm{keV}$ to $1332 \mathrm{keV}$ [8].

With regard to energy efficiency and calibration of the BEGe detector, a multi-energy certified standard was analyzed under the same conditions and geometry of the studied samples. This standard contains several emitting radionuclides $\gamma$ such as ${ }^{241} \mathrm{Am}(60 \mathrm{keV}),{ }^{109} \mathrm{Cd}(88 \mathrm{keV}),{ }^{57} \mathrm{Co}(122,136 \mathrm{keV}){ }^{139} \mathrm{Ce}(165 \mathrm{keV}),{ }^{51} \mathrm{Cr}(320$ $\mathrm{keV}){ }^{113} \mathrm{Sn}(391 \mathrm{keV}),{ }^{85} \mathrm{Sr}(514 \mathrm{keV}),{ }^{137} \mathrm{Cs}(661 \mathrm{keV}),{ }^{88} \mathrm{Y}(898,1836 \mathrm{keV})$ and ${ }^{60} \mathrm{Co}(1173,1332 \mathrm{keV})$. The samples of coal ash have been conditioned by SG50 and geometry set during 263000 seconds counting; a little less than 74 hours. Treatment of amplitude spectra was carried out with automatic counting software (Genie 2000) [8] to give directly the activity concentration of each radioactive element present in the sample.

The radionuclides, in which we are interested, are the radium 226, the thorium 232 and the potassium 40. ${ }^{226} \mathrm{Ra}$ is difficult to differentiate from ${ }^{235} \mathrm{U}$; as they emit photons with very close energies; $186.1 \mathrm{keV}$ and 185.72 $\mathrm{keV}$, respectively, and the interference can be created. The activity of ${ }^{226} \mathrm{Ra}$ can be performed from the ${ }^{214} \mathrm{~Pb}$ (295 keV and $352 \mathrm{keV}$ rays) and ${ }^{214} \mathrm{Bi}(609 \mathrm{keV}, 1120 \mathrm{keV}$ and $1764 \mathrm{keV}$ rays) after establishment of the secular equilibrium between ${ }^{226} \mathrm{Ra},{ }^{222} \mathrm{Rn},{ }^{214} \mathrm{~Pb}$ and the ${ }^{214} \mathrm{Bi}$. ${ }^{232} \mathrm{Th}$ has a ray at $63.81 \mathrm{keV}$ which has a very low emission probability of $0.263 \%$. This ray interferes with that of ${ }^{234} \mathrm{Th}$ at $63.28 \mathrm{keV}$ which has a higher transmission probability equal to $4.1 \%$. The determination of ${ }^{232} \mathrm{Th}$ activity is from the ${ }^{228} \mathrm{Ac}(911 \mathrm{keV}$ and $969 \mathrm{keV}$ rays) and ${ }^{212} \mathrm{~Pb}$ (239 keV ray). Given the short period (56 s) of ${ }^{220} \mathrm{Rn}$ decay that secular equilibrium is reached quickly 
for the thorium family. The ${ }^{40} \mathrm{~K}$ is determined from the $1461 \mathrm{keV}$ ray with $10.55 \%$ emission intensity.

\subsection{Surface Radon Exhalation Rate}

In this paragraph, we describe the process and experimental set up used to estimate the radon exhalation rate of ashes samples analyzed by gamma spectrometry. Exhalation is the mechanism which a radon atom produces a gas inside the sample reaching its surface. It groups precisely two steps: the emanation and transport. It is commonly expressed as surface flow exhalation radon $\left(\mathrm{Bq} \cdot \mathrm{m}^{-2} \cdot \mathrm{s}^{-1}\right)$. In the laboratory, for samples measurements we use the term of surface radon exhalation rate $\left(\mathrm{Bq} \cdot \mathrm{m}^{-2} \cdot \mathrm{h}^{-1}\right)$ [9]-[11].

Each amount of sample fly and bottom ashes ( $50 \mathrm{~g}$ ) were placed in the cylindrical "cans" as shown in Figure 2. The Solid-State Nuclear Track Detectors (SSNTD) LR115 type II non strippable $\left(2 \times 2 \mathrm{~cm}^{2}\right)$ was fixed on the top inside of the "can".

These films badges are LR115 type nuclear track ones produced by KODAK and they consist of a $100 \mu \mathrm{m}$ thick polyester substrate coated with a $12 \mu \mathrm{m}$ thick layer of red colored cellulose nitrate $\left(\mathrm{C}_{6} \mathrm{H}_{8} \mathrm{~N}_{2} \mathrm{O}_{9}\right)$. It can record energy particles between 1.4 and $4.7 \mathrm{MeV}$ with an incidence angle up to $50^{\circ}$. Alpha particles traverse the detector leaving various holes with diameters depending to the incident energy. After two months of irradiation, the LR115 was chemically treated in $2.5 \mathrm{~N}$ sodium hydroxide solution $(\mathrm{NaOH})$ at $60^{\circ} \mathrm{C}$ for time periods of 100 min. An optical microscope was used to read the developed films.

The density of traces per unit area and per unit time $D_{L R}$ in the LR115 and the volumetric activity of radon $A_{V}^{R n}$ are related by the following relationship:

$$
D_{L R}=\varepsilon_{L R}\left(\theta_{c}, E_{\alpha}\right) A_{V}^{R n}
$$

where $\varepsilon_{L R}\left(\theta_{c}, E_{\alpha}\right)$ is the efficiency of detection based on the critical recording angle $\theta_{c}$, and the energy of the alpha particle $E_{\alpha}$ calculated numerically [12]. This efficiency is equal to $0.0258\left(\right.$ traces $\cdot \mathrm{cm}^{-2} \cdot \mathrm{d}^{-1} / \mathrm{Bq} \cdot \mathrm{m}^{-3}$ ).

Exhalation rate ${ }^{222} \mathrm{Rn}$ is obtained from the following expression [13] [14]:

$$
E_{X}=\frac{A_{V}^{R n} V \lambda_{R n}}{S_{e}\left[t+\left(\frac{1}{\lambda_{R n}}\right)\left(\mathrm{e}^{-\lambda_{R n} t}-1\right)\right]}
$$

where $E_{X}$ is measured in $\left(\mathrm{Bq} \cdot \mathrm{m}^{-2} \cdot \mathrm{h}^{-1}\right) ; \quad A_{v}^{R n}$ is the volumetric activity of radon $\left(\mathrm{Bq} \cdot \mathrm{m}^{-3} \cdot \mathrm{h}\right) ; \quad \lambda_{R n}$ is the decay constant for radon $\left(\mathrm{h}^{-1}\right) ; S_{e}$ is the sample surface $\left(\mathrm{m}^{2}\right) ; V$ is the effective volume of can $\left(\mathrm{m}^{3}\right)$ and $t$ is the exposure time (h).

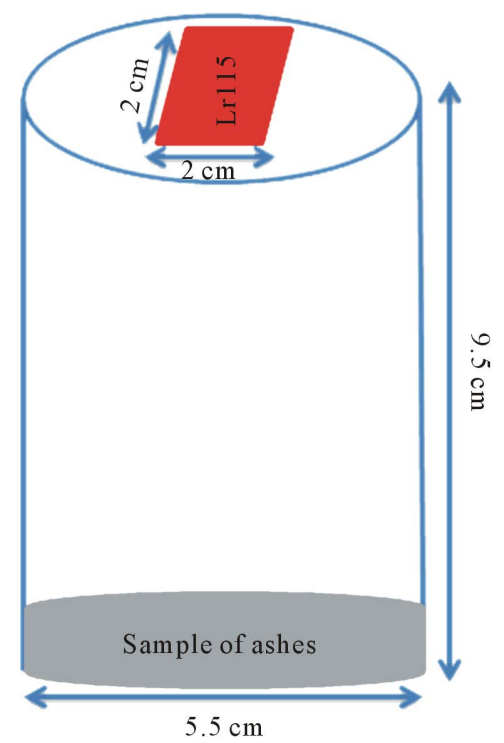

Figure 2. Diagram dosimeter to measure the exhalation of radon in samples of coal ash at thermal power plant JLEC. 


\subsection{Evaluation of the Radiological Effects and Dose Estimation}

In recent years, fly and bottom ashes have become a topic of great interest in the world because of the diversity of their uses in building materials. For this purpose, to evaluate the radiological hazards of fly and bottom ashes from the thermal power plant JLEC due to non-uniform distribution of radionuclides in the samples of coal ash, the UNSCEAR 2000 report [15] offers templates to define some dosimetric quantities such as radium equivalent, the index of internal/external hazard, the flow of the absorbed dose and the annual effective dose. Certain limits not to be exceeded are recommended.

\subsubsection{Radium Equivalent Ra}

To represent the level of activity of ${ }^{226} \mathrm{Ra},{ }^{232} \mathrm{Th}$ and ${ }^{40} \mathrm{~K}$ by a single quantity, a common radiological index was introduced. This index is known as the equivalent radium activity symbolized by $\mathrm{Ra}_{\mathrm{eq}}$ and calculated using the following expression:

$$
\mathrm{Ra}_{\mathrm{eq}}=\mathrm{A}_{226 \mathrm{Ra}}+1.43 \mathrm{~A}_{232 \mathrm{Th}}+0.077 \mathrm{~A}_{40 \mathrm{~K}}
$$

This relationship is obtained by considering that the activities $1 \mathrm{~Bq} / \mathrm{kg}$ of ${ }^{226} \mathrm{Ra}, 0.7 \mathrm{~Bq} / \mathrm{kg}$ of ${ }^{232} \mathrm{Th}$ and 13 $\mathrm{Bq} / \mathrm{kg}$ of ${ }^{40} \mathrm{~K}$ produce the same dose of gamma rays [16] [17].

It should be noted that the maximum value of the activity of radium equivalent in construction materials must be less than $370 \mathrm{~Bq} / \mathrm{kg}$.

\subsubsection{Internal and External Hazard Indices}

The hazard indices are defined by a model taking into account the maximum activity of $\mathrm{Ra}_{\mathrm{eq}}(370 \mathrm{~Bq} / \mathrm{kg})$. The $\mathrm{H}_{\mathrm{ex}}$ external hazard index is given by:

$$
\mathrm{H}_{\mathrm{ex}}=\frac{\mathrm{A}_{226 \mathrm{Ra}}}{370}+\frac{\mathrm{A}_{232 \mathrm{Th}}}{259}+\frac{\mathrm{A}_{40 \mathrm{~K}}}{4810} .
$$

In addition to the external hazard, the respiratory organs are threatened because of the disintegration of ${ }^{226} \mathrm{Ra}$ and ${ }^{222} \mathrm{Rn}$ and their descendants. The maximum permissible activity for ${ }^{226} \mathrm{Ra}$ has been reduced in half the value of $185 \mathrm{~Bq} / \mathrm{kg}$. The internal hazard $\mathrm{H}_{\text {in }}$ must be quantified:

$$
\mathrm{H}_{\text {in }}=\frac{\mathrm{A}_{226 \mathrm{Ra}}}{185}+\frac{\mathrm{A}_{232 \mathrm{Th}}}{259}+\frac{\mathrm{A}_{40 \mathrm{~K}}}{4810} \text {. }
$$

The maximum value of each index is tolerable with the unit value for the upper limit of $\mathrm{Ra}_{\mathrm{eq}}$.

\subsubsection{Absorbed Dose Rate and Annual Effective Dose}

The absorbed dose rate $\dot{\mathrm{D}}(\mathrm{nGy} / \mathrm{h})$ from natural radionuclides in the air at $1 \mathrm{~m}$ height is defined by expression (6):

$$
\dot{\mathrm{D}}(\mathrm{nGy} / \mathrm{h})=0.462 \mathrm{~A}_{226 \mathrm{Ra}}+0.604 \mathrm{~A}_{232 \mathrm{Th}}+0.0417 \mathrm{~A}_{40 \mathrm{~K}} \text {. }
$$

The received dose by the population is called annual effective dose, it calculated by the following equation:

$$
\dot{\mathrm{E}}(\mathrm{mSv} / \mathrm{y})=\dot{\mathrm{D}}(\mathrm{nGy} / \mathrm{h}) \times 8760(\mathrm{~h}) \times 0.2 \times 0.7(\mathrm{~Sv} / \mathrm{Gy}) 10^{-6} .
$$

The annual effective dose rates should be obtained to test the health effect of those absorbed dose rates. In order to estimate the annual effective doses, one has to take into account to conversion coefficient from absorbed dose in air to effective and the outdoor occupancy factor. In the UNSCEAR reports [15], a value of 0.7 Sv/Gy was used for the conversion coefficient from absorbed dose in air to effective dose received by adults and 0.2 for the outdoor occupancy factor.

\section{Results and Discussion}

The specific activities of radionuclides ${ }^{226} \mathrm{Ra},{ }^{232} \mathrm{Th}$ and ${ }^{40} \mathrm{~K}$ were determined by gamma spectrometry in samples of fly and bottom ashes from thermal power plant JLEC and other thermal plants of some European countries are regrouped in Table 1.

According to the qualitative analysis of spectra obtained for both samples of fly and bottom ashes, we find practically all radionuclides of natural radioactive families $\left({ }^{238} \mathrm{U},{ }^{232} \mathrm{Th},{ }^{235} \mathrm{U}\right.$ and $\left.{ }^{40} \mathrm{~K}\right)$. 
By examining the results in Table 1, the first observation is that the specific activities of elements ${ }^{226} \mathrm{Ra},{ }^{232} \mathrm{Th}$ and ${ }^{40} \mathrm{~K}$ in the sample of fly ash are higher compared to those found in the bottom ash with factors of 2.07, 1.77 and 1.32 for ${ }^{40} \mathrm{~K},{ }^{226} \mathrm{Ra}$ and ${ }^{232} \mathrm{Th}$, respectively.

The activities of ${ }^{226} \mathrm{Ra}$ and ${ }^{232} \mathrm{Th}$ in both ash samples are well above the permissible activity which is in the order of $40 \mathrm{~Bq} / \mathrm{kg}$, while the activity of ${ }^{40} \mathrm{~K}$ is less than $370 \mathrm{~Bq} / \mathrm{kg}$ [15] even if the activity of ${ }^{40} \mathrm{~K}(348 \mathrm{~Bq} / \mathrm{kg})$ in the sample of fly ash is very close to the eligible activity.

The levels of ${ }^{226} \mathrm{Ra},{ }^{232} \mathrm{Th}$ and ${ }^{40} \mathrm{~K}$ measured in our samples of coal ash from thermal power plant JLEC are comparable to those found in other thermal power plants in Europe.

Table 2 shows that the values of $\mathrm{Ra}_{\mathrm{eq}}, \mathrm{H}_{\mathrm{ex}}$ and $\mathrm{H}_{\text {in }}$ in fly ash and bottom ash are below the maximum values defined by the UNSCEAR 2000 report [15], except for the value of the $\mathrm{H}_{\mathrm{in}}(1.28)$ in fly ash that remains a little higher than the unit.

The absorbed gamma dose rates measured in the samples of fly and bottom ashes are of the order of 146 $\mathrm{nGy} / \mathrm{h}$ and $93 \mathrm{nGy} / \mathrm{h}$, respectively. After conversion of these values, the annual effective dose of these samples of fly and bottom ashes are on the order of $0.18 \mathrm{mSv} / \mathrm{y}$ and $0.11 \mathrm{mSv} / \mathrm{y}$, respectively. Those values not exceeding the annual effective dose limit set of $1 \mathrm{mSv} / \mathrm{y}$.

The results presented in Table 3 show that the values of activity concentrations of radon and the rate of surface exhalation in the bottom ash samples are higher than those of the samples of fly ash. The exhalation of radon levels in coal ash samples are below the world average $\left(57.6 \mathrm{~Bq} \cdot \mathrm{m}^{-2} \cdot \mathrm{h}^{-1}\right)$ [15]. These results agree with those found by other authors (Table 3).

\begin{tabular}{|c|c|c|c|c|}
\hline \multirow{2}{*}{ Thermal Power Plants } & \multirow{2}{*}{ Sample } & \multicolumn{3}{|c|}{ Activity in Bg/kg } \\
\hline & & ${ }^{226} \mathrm{Ra}$ & ${ }^{232} \mathrm{Th}$ & ${ }^{40} \mathrm{~K}$ \\
\hline \multirow{2}{*}{$\begin{array}{l}\text { JLEC-Morocco } \\
\text { (Present Study) }\end{array}$} & FA & $149 \pm 26$ & $104 \pm 18$ & $348 \pm 47$ \\
\hline & $\mathrm{BA}$ & $84 \pm 16$ & $79 \pm 15$ & $168 \pm 30$ \\
\hline \multirow{2}{*}{ Serbia (2011) [18] } & FA & 120 & 72 & 360 \\
\hline & $\mathrm{BA}$ & 65 & 39 & 241 \\
\hline \multirow{2}{*}{ Spain (2009) [19] } & FA & $191 \pm 9$ & $74 \pm 3$ & $306 \pm 13$ \\
\hline & BA & $149 \pm 6$ & $66 \pm 3$ & $235 \pm 11$ \\
\hline \multirow{2}{*}{ Turkey (2008) [20] } & FA & $149 \pm 2$ & $58 \pm 4$ & $94 \pm 28$ \\
\hline & $\mathrm{BA}$ & $50 \pm 1$ & $25 \pm 2$ & $376 \pm 9$ \\
\hline \multirow{2}{*}{ Greece (2004) [21] } & FA & $904 \pm 9$ & $53 \pm 5$ & $454 \pm 11$ \\
\hline & BA & $662 \pm 9$ & $44 \pm 5$ & $405 \pm 11$ \\
\hline
\end{tabular}

Table 2. Radium equivalent $\mathrm{Ra}_{\mathrm{eq}}$, internal hazard index $\mathrm{H}_{\mathrm{in}}$, external hazard index $\mathrm{H}_{\mathrm{ex}}$, absorbed dose rate $\dot{\mathrm{D}}$ and annual effective dose $\dot{\mathrm{E}}$ in ash coal.

\begin{tabular}{cccccc}
\hline Sample & $\mathrm{Ra}_{\mathrm{eq}}(\mathrm{Bq} / \mathrm{kg})$ & $\mathrm{H}_{\mathrm{ex}}$ & $\mathrm{H}_{\mathrm{in}}$ & $\dot{\mathrm{D}}(\mathrm{nGy} / \mathrm{h})$ & $\dot{\mathrm{E}}(\mathrm{mSv} / \mathrm{y})$ \\
\hline Fly Ash & $324 \pm 30$ & 0.88 & 1.28 & $146 \pm 9$ & $0.18 \pm 0.01$ \\
Bottom Ash & $210 \pm 28$ & 0.57 & 0.79 & $93 \pm 6$ & $0.11 \pm 0.01$ \\
\hline
\end{tabular}

Table 3. Experimental results of the volume activity of radon $A_{v}^{R n}$ and the surface exhalation rate $E_{X}$ in samples of ash coal JLEC.

\begin{tabular}{cccc}
\hline Thermal Plants & Sample & $A^{R n}\left(\mathrm{~Bq} / \mathrm{m}^{3}\right)$ & $E_{X}\left(\mathrm{mBq} \cdot \mathrm{m}^{-2} \cdot \mathrm{h}^{-1}\right)$ \\
\hline JLEC-Morocco & FA & $337 \pm 27$ & $276 \pm 22$ \\
(Our Study) & BA & $465 \pm 38$ & $381 \pm 31$ \\
India (2013) [22] & FA & $431.70 \pm 35.50$ & $155.00 \pm 12.8$ \\
India (2010) [23] & FA & 214 to 590 & 138 to 381 \\
\hline
\end{tabular}




\section{Conclusions}

In this study, we assess radiation risks due to natural radioactivity in fly and bottom ashes from thermal power plant of JLEC. For this ending, we measured the natural radioactivity in these samples using gamma spectrometry technique. The activities of ${ }^{226} \mathrm{Ra}$ and ${ }^{232} \mathrm{Th}$ in both ashes samples are well above the permissible activity, which is on the order of $40 \mathrm{~Bq} / \mathrm{kg}$, while the ${ }^{40} \mathrm{~K}$ activity is less than $370 \mathrm{~Bq} / \mathrm{kg}$. Based on the models proposed by the UNSCEAR, our analyses reveal that $\mathrm{H}_{\mathrm{ex}}$ and $\mathrm{H}_{\mathrm{in}}$ values for fly and bottom ashes are below the standard value, except for the one of $\mathrm{H}_{\mathrm{in}}$ (1.28) in the fly ash, which is a little more than unity. The values obtained for the equivalent radium and annual effective doses of the fly and bottom ashes are (324 Bq/kg and $210 \mathrm{~Bq} / \mathrm{kg})$ and $(0.18 \mathrm{mSv} / \mathrm{y}$ and $0.11 \mathrm{mSv} / \mathrm{y})$, respectively. These values do not exceed the recommended limits which are 370 $\mathrm{Bq} / \mathrm{kg}$ and $1 \mathrm{mSv} / \mathrm{y}$, respectively.

To estimate the Exhalation of radon levels in coal ash, we used the alpha dosimetry based on quantitative exploitation of LR115 detector. Exhalation rates found for samples of fly and bottom ashes are $276 \mathrm{mBq} \cdot \mathrm{m}^{-2} \cdot \mathrm{h}^{-1}$ and $381 \mathrm{mBq} \cdot \mathrm{m}^{-2} \cdot \mathrm{h}^{-1}$, respectively; these values remain below the eligible limit $\left(57.6 \mathrm{~Bq} \cdot \mathrm{m}^{-2} \cdot \mathrm{h}^{-1}\right)$.

During our work, we find that the results for our samples of coal ash from thermal power plant JLEC are comparable to those obtained in other countries.

Based on the above results, we can conclude that the fly and bottom ashes from thermal power plant of JLEC can be classified in the category of products exempt from any usage restrictions. Therefore, these coal ashes did not present, in any case, a health risk to the public and can be effectively used in various construction activities.

\section{References}

[1] Office National d’Électricité et de l’Eau Potable (ONEEP) (2012) Rapport: Le Marché de l’Energie Electrique au Maroc, Branche Electricité.

[2] Beck, H.L. (1989) Radiation Exposures Due to Fossil Fuel Combustion. International Journal of Radiation Applied Instruments, Part C. Radiation Physics Chemistry, 34, 285-293.

[3] Papastefanou, C. (2010) Escaping Radioactivity from Coal-Fired Power Plants (CPPs) Due to Coal Burning and the Associated Hazards: A Review. Journal of Environmental Radioactivity, 101, 191-200. http://dx.doi.org/10.1016/j.jenvrad.2009.11.006

[4] Commission Canadienne de la Sûreté Nucléaire (CCSN) (2011) Le radon et la santé.

[5] United Nation Scientific Committee on the Effects of Atomic Radiation (UNSCEAR) (2006) Report annex E, Sources of Effect Assessment for Radon in Homes and Workplaces.

[6] TAQA Morocco (2013) Rapport Annuel.

[7] EL Moudni, E.S., Monkade, M. and Lahlou, K. (2009) Valorisation du Mélange Cendres de Foyer de Jorf LasfarScories de l'Aciérie Sonasid dans les Chaussées Routières. Revue Francophone d'Ecologie Industrielle: Déchets, Sciences \& Techniques (DST), 56, 4è Trimestre.

[8] Canberra (2005) Genie 2000, Version 3.2. Canberra Industries, Inc., Canberra France HQ \& Europe Coordination Bois Mouton, France.

[9] Singh, A.K., Sengupta, D. and Prasad, R. (1999) Radon Exhalation Rate and Uranium Estimation in Rock Samples from Bihar Uranium and Copper Mines Using the SSNTD Technique. Applied Radiation and Isotopes, 51, 107-113. http://dx.doi.org/10.1016/S0969-8043(98)00152-3

[10] Tufail, M., Sikander, M.M., Arif, M., Qureshi, A.A., Yasir, A. and Khan, H.A. (2000) Application of a "Closed-Can” Technique for Measuring Radon Exhalation from Mine Samples of Punjab, Pakistan. Journal of Environmental Radioactivity, 50, 267-275. http://dx.doi.org/10.1016/S0265-931X(00)00016-3

[11] Sharma, D.K., Kumar, A., Kumar, M. and Singh, S. (2003) Study of Uranium, Radium and Radon Exhalation Rate in Soil Samples From Some Areas of Kangra District, Himachal Pradesh, India Using Solid-State Nuclear Track Detectors. Radiation Measurements, 36, 363-366. http://dx.doi.org/10.1016/S1350-4487(03)00152-5

[12] Pape, A., Adloff, J.C., Barillon, R., Haessler, A., Hoernel, A., Nourreddine, A., Oster, D. and Weidmann, D. (1998) Quantitative Alpha-Particle Detection in a Homogeneous Medium with LR115. Nuclear Instruments and Methods in Physics Research Section B: Beam Interactions with Materials and Atoms, 143, 557-560. http://dx.doi.org/10.1016/S0168-583X(98)00398-X

[13] Abu-Jarad, F., Fremlin, J.H. and Bull, R. (1980) A Study of Radon Emitted From building Materials Using Plastic $\alpha$-track Detectors. Physics Medicine and Biology, 25, 683-694. http://dx.doi.org/10.1088/0031-9155/25/4/007

[14] Khan, A.J., Tyagi, R.K. and Prasad, R. (1989) Study of Airborne Radon Levels Inside Buildings. International Journal 
of Radiation Applications and Instrumentation. Part D. Nuclear Tracks and Radiation Measurements, 16, $23-27$. http://dx.doi.org/10.1016/1359-0189(89)90006-X

[15] United Nations Scientific Committee on the Effects of Atomic Radiation (UNSCEAR) (2000) Sources and Effects of Ionizing Radiation. United Nations, New York.

[16] Beretka, J. and Matthew, P.J. (1985) Natural Radioactivity of Australian Building Materials, Industrial Wastes and By-Products. Health Physics, 48, 87-95. http://dx.doi.org/10.1097/00004032-198501000-00007

[17] Hewamanna, R., Sumithrarachchi, C.S., Mahawatte, P., Nanayakkara, H.L.C. and Ratnayake, H.C. (2001) Natural Radioactivity and Gamma Dose from Sri Lankan Clay Bricks Used in Building Construction. Applied Radiation and Isotopes, 54, 365-369. http://dx.doi.org/10.1016/S0969-8043(00)00107-X

[18] Janković, M.M., Todorović, D.J. and Nikolić, J.D (2011) Analysis of Natural Radionuclides in Coal, Slag and Ash in Coal-Fired Power Plants in Serbia. Journal Mining and Metallurgy Section B-Metallurgy, 47, 149-155. http://dx.doi.org/10.2298/JMMB110208008J

[19] Mora, J.C., Baeza, A., Robles, B., Corbacho, J.A. and Cancio, D. (2009) Behaviour of Natural Radionuclides in Coal Combustion. Radioprotection, 44, 577-580. http://dx.doi.org/10.1051/radiopro/20095106

[20] Cevik, U., Damla, N., Koz, B. and Kaya, S. (2008) Radiological Characterization Around the Afsin-Elbistan CoalFired Power Plant in Turkey. Energy \& Fuels, 22, 428-432. http://dx.doi.org/10.1021/ef700374u

[21] Karangelos, D.J., Petropoulos, N.P., Anagnostakis, M.J., Hinis, E.P. and Simopoulos, S.E. (2004) Radiological Characteristics and Investigation of the Radioactive Equilibrium in the Ashes Produced in Lignite-Fired Power Plants. Journal of Environmental Radioactivity, 77, 233-246. http://dx.doi.org/10.1016/j.jenvrad.2004.03.009

[22] Gupta, M., Mahur, A.K., Varshney, R., Sonkawade, R.G., Verma, K.D. and Prasad R. (2013) Measurement of Natural Radioactivity and Radon Exhalation Rate in Fly Ash Samples From a Thermal Power Plant and Estimation of Radiation Doses. Radiation Measurements, 50, 160-165. http://dx.doi.org/10.1016/j.radmeas.2012.03.015

[23] Kant, K., Rashmi, Kuriakose, S., Sonkawade, R.G., Chauhan, R.P., Chakarvarti, S.K. and Sharma G.S. (2010) Radon Activity and Exhalation Rates in Indian Fly Ash Samples. Indian Journal of Pure \& Applied Physics, 48, 457-462.

Submit or recommend next manuscript to SCIRP and we will provide best service for you:

Accepting pre-submission inquiries through Email, Facebook, Linkedin, Twitter, etc A wide selection of journals (inclusive of 9 subjects, more than 200 journals)

Providing a 24-hour high-quality service

User-friendly online submission system

Fair and swift peer-review system

Efficient typesetting and proofreading procedure

Display of the result of downloads and visits, as well as the number of cited articles

Maximum dissemination of your research work

Submit your manuscript at: http://papersubmission.scirp.org/ 